\title{
YOUNG WORKERS HEALTH AND SAFETY : A SUMMARY OF LITERATURE REVIEW
}

\author{
YahyaThamrin \\ Safety and Health Department, Faculty of Public Health Hasanuddin University, Indonesia
}

\begin{abstract}
Aims: The purpose paper aims to report a vulnerability of young workers regarding their health and safety.

Design/methodology/approach: A systematic search was conducted through PubMed, Scopus, Web of Science, Science Direct and Google Scholar using terms of interest in a logic grid with key words "young workers" and "health and safety". The articles in this search were limited to those published between 2002 and 2012. Nine studies ( 9 papers) met the inclusion criteria and were independently reviewed.

Findings : Majority of the studies in this synopsis indicate education is a key to reduce young workers injury. In the other hands, the current safety education and training for young workers apparently are not effective due to the training uses similar method that is applied to adult workers, which is not suited to youths' developmental levels or interest. Furthermore, the safety training also should focus not only on providing information for identifying reasons for workplace injuries and young workers' rights but should be also embedded into workplace safety education programs. The safety training should become a priority in health education programs applied in schools.

Research limitations/implications: Due to the necessary Australia focus and time constraints, only studies from Canada, USA, New Zealand and Denmark were included.

Originality/value: The paper shows that there is a evidence base that education and knowledge about hazards interventions can positively reduce young workers injury.
\end{abstract}

Keywords: Young workers, work safety, workplace injury. 


\section{INTRODUCTION}

Young workers represent a significant proportion of people injured at work (Thamrin et al. 2010). There is evidence that the risk of occupational injury is inversely related to the worker's age. According to WorkSafe Victoria (2007), young workers are people who working permanently full or part time, casually full or part time, on labour hires, as apprentices or trainees and as part of a work experience or structural workplace learning program and they are generally at the age between 15 and 24 years old. However, in practice, the situation is more complex than this suggests. There are a number of ways to define young people, which can be dependent upon particular data collections.

In most countries, young people aged 15 yearsand over are permitted to work or leave school, while in some jurisdictions the legal compulsory age of leaving school is higher than 15 years. As such, children under the age of 15 years are generally regarded as dependent on their parents for support, wellbeing and development. Eighteen is the legal age at which young people attain adulthood, are allowed to vote, usually finish senior school and undertake the transition to independent living and/or further studies. Consequently, a number of data collections use age 18 as the cut-off point between adolescence and adulthood (Fraser, 2002; Pitman, 2003).

Young people working in certain industries may be at increased risk for injury because the industry setting often involves the hazards that are encountered. Retail trade accounts for the largest proportion of nonfatal youth injuries, most of which occur in restaurants and grocery stores (Runyan, 2000). For instance, restaurant work requires the use of stoves and the handling of hot grease, which contributes to the high incidence of burns in these workers. Grocery store workers use case cutters and other sharp objects that may cause lacerations (Runyan, 2000). Risk taking behaviour and exposure to prohibited tasks may increase risk of injury among youths. A study interviewed 146 teens treated for workplace injuries in emergency rooms, it was found that $19 \%$ of their injuries occurred while they were engaged in risk taking and prohibited tasks (Knight et al, 1995).

There are some industries where the young people are much more attached than other industries. Hospitality and retail sectors are one of those industries which include all businesses that provide food, beverages, and/or accommodation services (Jahan et al, 2010). This covers restaurants; pubs, bars and clubs; hotels; contract catering; hospitality services. More than half of U.S. teenagers work in the retail industry, including restaurants, grocery stores, and other retail establishments (Bureau of Labour Statistics, USA 1999). According to the European Agency for Safety and Health at Work, the hospitality sector is the number one employment sector for young workers (EASHW, 2007). In Australia, by 2003, more than half the teenage $(67 \%)$ labour force was employed in retail trade or accommodation, cafes and restaurants (Brosnan, 2006).

There are many research has been published regarding the vulnerability of young workers. The table 1 presents the summary of publications on young workers' health and safety.

\section{METHODS}

A systematic search was conducted through PubMed, Scopus, Web of Science, Science Direct and Google Scholar using terms of interest in a logic grid with key words "young workers" and "health and safety". The articles in this search were limited to those published between 2002 and 2012. 
Table 1Young Workers Health and Safety

\begin{tabular}{|c|c|c|c|}
\hline $\begin{array}{c}\text { Category of } \\
\text { review }\end{array}$ & $\begin{array}{c}\text { Author \& } \\
\text { Country }\end{array}$ & Title & Main Findings \\
\hline $\begin{array}{l}\text { General } \\
\text { review }\end{array}$ & $\begin{array}{l}\text { (Chin et al. } \\
\text { 2010)/ } \\
\text { Canada }\end{array}$ & $\begin{array}{l}\text { Enabling youth } \\
\text { to advocate for } \\
\text { workplace safety }\end{array}$ & $\begin{array}{l}\text { This research examined safety education programs for youth workers in Canada with an } \\
\text { emphasis on how well these programs promote self-advocacy skills in youth workers. } \\
\text { Documents of youth workplace safety education initiatives sponsored by government and } \\
\text { non-governmental agencies were analysed systematically in this study. Results from this } \\
\text { research revealed that safety programs for young workers in Canada merely focus on } \\
\text { providing youth workers with knowledge of their rights and identifying reasons for youth } \\
\text { injury on the job. The programs only do little in the way of supporting worker self-advocacy } \\
\text { especially in the areas of knowledge of self, communication and leadership. The study } \\
\text { recommends that principles of self-advocacy should be embedded into workplace safety } \\
\text { education programs. }\end{array}$ \\
\hline $\begin{array}{l}\text { General } \\
\text { review }\end{array}$ & $\begin{array}{l}\text { (Walters et } \\
\text { al. 2010)/ } \\
\text { United } \\
\text { States }\end{array}$ & $\begin{array}{l}\text { Occupational } \\
\text { injuries to } \\
\text { Oregon } \\
\text { workers } 24 \text { years } \\
\text { and younger: An } \\
\text { analysis of } \\
\text { workers' } \\
\text { compensation } \\
\text { claims, 2000- } \\
2007\end{array}$ & $\begin{array}{l}\text { This study conducted to describe and estimate rates of occupational injuries to workers } \\
\text { younger than } 25 \text { years of age in Oregon during an } 8 \text {-year period. Oregon workers' } \\
\text { compensation disabling claims data and one commercial insurance carrier's non-disabling } \\
\text { claims data were analysed. The study found that injuries were more frequent among } 22-24 \\
\text { year olds and among males. However, females have higher proportion of claims in the } \\
\text { youngest age group. Sprain or strain was reported as the most common injury, though } \\
\text { lacerations and burns were more frequently reported in the } 14-18 \text { year olds. The rate of injury } \\
\text { for } 14-18 \text { year olds doubled when non-disabling claims were included. The overall rate of } \\
\text { injury was } 122.7 / 10,000 \text { workers, but was higher in the construction, manufacturing, and } \\
\text { transportation sectors, and in the forestry, agriculture, fishing and hunting sector for older } \\
\text { teens and young adults. This information supports the evidence that teenagers and young } \\
\text { adults are at risk for work-related injuries, illnesses, and fatalities. This study also suggested } \\
\text { that special attention should be given to older teen workers, who are not covered under child } \\
\text { labour laws but may still lack the emotional or cognitive maturity to perform higher-risk } \\
\text { tasks. }\end{array}$ \\
\hline General & (Anderson et & The good, the & This study examined recent initiatives designed to address the health and safety of young \\
\hline
\end{tabular}




\begin{tabular}{lll}
\hline review & al. 2011a)/ & bad and the ugly: \\
& New & The health and \\
& Zealand & safety of young \\
& workers
\end{tabular}

$\begin{array}{lll}\text { Empirical } & \text { (Blair et al. } & \text { Safety beliefs } \\ \text { study } & \text { 2004)/ } & \text { and safe } \\ & \text { United } & \text { behaviour } \\ \text { among mid- } \\ \text { States } & \text { western college } \\ & & \text { students }\end{array}$

$\begin{array}{lll}\text { Empirical } & \text { (Westaby } & \text { Risk-Taking } \\ \text { study } & \text { and Lowe } & \text { orientation and } \\ & \text { 2005)/ } & \text { injury among } \\ & \text { United } & \text { youth workers: } \\ & \text { States } & \text { Examining } \\ & & \text { thesocial } \\ & & \text { influence of } \\ & \text { supervisors, co- } \\ & & \text { workers, and } \\ & & \text { parents }\end{array}$

Empirical (Zierold and Severe injury

study Anderson and the need for workers in New Zealand. The research found evidence that young workers are vulnerable because are frequently exposed to hazardous conditions for low pay and are concentrated in industries where precarious employment is prevalent, such as agriculture, manufacturing, and service. This research also found that many of young workers are to some extent invisible and not recorded in the official injury and compensation records because they are probably fall outside the conventional state apparatus designed to protect workers and assist injured or ill adults.

This research explored the impact of safety beliefs on safe behaviour and the effect of age, gender, class standing, and geographic region on these beliefs and behaviours. The study found that there were significant main effects for gender and age on safety beliefs and safe behaviour and a significant interaction between gender and age for both outcome variables. The level of safety beliefs and safe behaviour of Midwestern college students in 1993 to those in 2002 was also compared in this research. Midwestern college students in 2002 were found less safety-conscious in terms of self-reported safety beliefs and safe behaviour than those in 1993. This findings show that for the period 1993-2002 safety education of adolescents and young adults in the United States has not been effective. In other words, social and school environment in 2002 is less conducive to the students' safe behaviour and beliefs than in 1993.

The study examined on how social influence and risk-taking orientation impact youth injury at work. The hypothesis in this study was that perceived supervisory influence, co-workers' risk taking, and parental risk taking serve as key exogenous variables of risk-taking orientation at work. The effect of parental risk takingfirstly was assumed to be mediated via global risk taking, but then was hypothesized to predict risk-taking orientation at work. Risktaking orientation was further hypothesized to serve as a direct predictor and full mediator of work injury. Longitudinal results from 2,542 adolescents working across a wide spectrum of jobs supported the notion that social perceptions about supervisors, co-workers, and parents serve as important factors underlying youths' risk-taking orientation at work, with coworkers' risk taking demonstrating a relatively strong effect.

This research evaluated work characteristics and safety training among teenagers with severe work related injuries. The study found $15 \%$ of teenaged workers reported being injured at the 


\begin{tabular}{|c|c|c|c|}
\hline & $\begin{array}{l}\text { 2006)/ } \\
\text { United } \\
\text { States }\end{array}$ & $\begin{array}{l}\text { improved safety } \\
\text { training among } \\
\text { working teens }\end{array}$ & $\begin{array}{l}\text { job. Variables associated with severe injury included having a near-miss incident at work, } \\
\text { working after 11:00 PM and being asked to do something dangerous. The results of this study } \\
\text { suggested methods that may reduce severe injuries in working teens are prohibiting them } \\
\text { from working long and late hours during the school week, proposing better communication } \\
\text { when a youth experiences a near-miss incident at work, or when a co-worker is injured, and } \\
\text { improving safety training. Safety training should be viewed as a priority in a health education } \\
\text { program provided by schools. }\end{array}$ \\
\hline $\begin{array}{l}\text { Empirical } \\
\text { study }\end{array}$ & $\begin{array}{l}\text { (Tucker and } \\
\text { Turner } \\
\text { 2011)/ } \\
\text { Canada }\end{array}$ & $\begin{array}{l}\text { Young worker } \\
\text { safety } \\
\text { behaviours: } \\
\text { Development } \\
\text { and validation of } \\
\text { measures }\end{array}$ & $\begin{array}{l}\text { This research carried out four studies to develop and validate measures of workplace safety- } \\
\text { related behaviours relevant to young workers in responses to deteriorating conditions. The } \\
\text { results of the studies maintain the validity and the reliability of a set of safety-related } \\
\text { behaviours; intentions to quit an unsafe job (exit), speaking out about safety concerns (voice), } \\
\text { adapting to a dangerous job hoping that safety conditions improve (patience), deliberately } \\
\text { letting safety conditions worsen (neglect), and following safety policies (compliance). This } \\
\text { set of behaviours is practical for safety interventions assessment of young workers and for } \\
\text { research in topic of safety-related behaviour. }\end{array}$ \\
\hline $\begin{array}{l}\text { Empirical } \\
\text { study }\end{array}$ & $\begin{array}{l}\text { (Rasmussen } \\
\text { et al. 2010)/ } \\
\text { Denmark }\end{array}$ & $\begin{array}{l}\text { Incidence of } \\
\text { Work Injuries } \\
\text { amongst Danish } \\
\text { adolescents and } \\
\text { their association } \\
\text { with work } \\
\text { environment } \\
\text { factors }\end{array}$ & $\begin{array}{l}\text { The objectives of this study were to evaluate the incidence of severe work injuries among } \\
\text { Danish adolescents and to find potential work environment factors associated with the } \\
\text { accidents. The results specified that around 5\% of the adolescents, who held a job, } \\
\text { experienced a work injury at the age of } 17 \text {. This equals an incidence of } 65 \text { accidents per } \\
\text { million working hours. Despite having decent working conditions, nearly } 50 \% \text { of adolescents } \\
\text { reported that their work was heavy, monotonous or psychologically demanding. These } \\
\text { conditions support increased the risk of experiencing work injuries. The research concluded } \\
\text { that the incidence of work injuries among adolescents was higher than the incidence among } \\
\text { adults. Adolescents' risk of experiencing a work injury was elevated significantly by lack of } \\
\text { social support from management. Hence, more direct supervision is proposed to prevent } \\
\text { adolescents' work injuries. }\end{array}$ \\
\hline $\begin{array}{l}\text { Empirical } \\
\text { study }\end{array}$ & $\begin{array}{l}\text { (Zierold et } \\
\text { al. 2012)/ } \\
\text { United } \\
\text { States }\end{array}$ & $\begin{array}{l}\text { Attitudes of } \\
\text { Teenagers } \\
\text { Towards } \\
\text { Workplace }\end{array}$ & $\begin{array}{l}\text { This research investigated the attitudes teens' worker towards safety training and how they } \\
\text { stay safe on the job. The study found that majority of teens agreed that safety training was } \\
\text { important, but they personally feel did not need it. They prefer to use their "common sense" } \\
\text { to stay safe on workplace. However more than } 50 \% \text { of teens reported workplace injuries. }\end{array}$ \\
\hline
\end{tabular}


Safety Training Most teens reported receiving safety training but some of them were unable to differentiate between safety training and job training. The method of safety training for teens' workers and adult workers is exactly the same which was not suited to teens' developmental levels or interest. Therefore the training became ineffective. This study suggested that safety training may be a powerful way to reduce injury rates among working teenagers, but the training methods should be geared towards teens' developmental levels or interest.

\section{DISCUSSION}

Occupational health and safety is an important concern for all working individuals. As $45 \%$ of the world population belongs to the workforce, occupational injuries and work related diseases have an important impact on health (Hulshof, 1999). Injuries and illnesses have a variety of causes and can occur in every type of workplace. The literature suggests that there is a significant relationship between age and occupational accidents and illnesses. Laflamme and Menckel (1995) outlined a framework through a review of literature to identify jobs in which aging has either a preventable or an aggravating effect on accident occurrence. Their findings suggest that accident frequency tends to decrease as age increases. Similar findings have also been found in the majority of the international literature(Jovanovic, 2004; Hertzman, 1999; Saarela, 2005). In Finland, the occupational accident incidence rate of the youngest age group was found to be nearly double compared to that for the oldest age group (Palukka and Salminen, 2005). In Australia, Scott et al (2004) reported comparable findings. They found that, the workers of the age group of 15 to 17 years were twice as likely to be injured in the workplace as other workers.

The research listed in Table 1 discusses young workers' health and safety. Research in the United States (Walters et al.
2010) and Denmark (Rasmussen et al. 2010) presents evidence that the incidence of work injuries among young workers is higher than among adults. Typically, young workers are concentrated in industries where precarious employment is prevalent, such as agriculture, manufacturing and service as described in studies in New Zealand (Anderson et al. 2011) and United States (Walters et al 2010).

Young people represent $14 \%$ of total population of Australia and they make up of $21 \%$ of employees. They comprise $40 \%$ of casual employment and $53.7 \%$ of full time employment (Australia Bureau of Statistics, 2006; Australian Institute of Health and Welfare, 2007). In Australia, young workers have the highest work injury rate. According to the survey of work related injuries conducted by the Australian Bureau of Statistics (ABS, 2006), people aged 15 to 24 years had the highest work-related injury rate (around 75 per 1000 employed people). Further, the Australian Safety and Compensation Council (ASCC, 2008) shows that 15 to 24 year olds have a $75 \%$ greater risk of being injured at work. ASCC also states that about 3000 workers die as a result of workplace injuries and illnesses each year. This causes a significant burden to Australia and annually estimated cost is $\$ 30$ billion. In South Australia 33 new and young workers are injured everyday (ASCC, 2008). 
Although, in South Australia, the government, industry and the community have placed a strong emphasis on young worker OHS education, injury data for young workers in South Australia are worse than the national average. In South Australia, young workers are 1.4 times more likely than the average worker to be injured at work and more than $70 \%$ of those injuries happen in their first year of employment. In South Australia, the workers compensation injury claim in 15-19 years of age is 6\% which is slightly higher than Australian national rate $(5 \%)$ (Minister for Industrial Relations, press release, May 2007).

Lack of experience and knowledge about hazards makes young workers susceptible to work related injury and hazards. Young people are undergoing physical and psychosocial development. They may be less compliant with OHS instructions, for example due to peer pressure or risk taking behaviour. The consequences of accidents to young people vary from minor injuries to permanent disabilities and even death (Saarela, 2005). Almost half of young workers (15-24 years) experience injuries in the first five months on the job (Hertzman, 1999). Webb also found in 1992 that workers less than three years experience were significantly more likely to have injuries than older workers. The majority of the young workers are students and many of them begin working in a regular part time job at the age of 14 or 15 . Most students work at temporary or intermittent jobs that require little technical skill and safety training may be limited, particularly in small businesses.

Some studies presented factorsthat escalate the incidence of injuries among young workers. Studies by Zierold et al. (2012) and Blair et al. (2004) claimed that the attitude of young workers towards safety intheworkplace is a determinant factor. Westaby and Lowe (2005) indicated that co- worker, supervisor and parents also contribute to the risk-taking orientationof youths. Moreover, Rasmussen et al. (2010) reported that young workers in Denmark found their work were heavy, monotonous, and psychologically demanding and reported it as a factor that increased rate of injuries.

Young workers also face problems associated with policy that affects their health and safety in a workplace. In New Zealand, many young workers are unlisted in the official injury and compensation records because they are not included in the conventional state apparatus designed to protect workers and assist injured or ill adults (Anderson et al. 2011). Walters et al. (2010) showed that young-adult workers in the United States are not covered under child labour laws but may still lack the emotional or cognitive maturity to perform higher-risk tasks.

\section{CONCLUSION}

Most studies in this review suggest that safety education is important to reduce injury for young workers. However, the current safety education and training for young workers are not effective. The reason for ineffective safety training for young workers is the training uses similar method that is applied to adult workers, but this is not suited to youths' developmental levels or interest. The safety training also should focus not only on providing information for identifying reasons for workplace injuries and young workers' rights. Self-advocacy should be embedded into workplace safety education programs. Moreover, safety training should be viewed as a priority in health education programs provided by schools. 


\section{REFERENCES}

Australian Bureau of Statistics. (2006).

Work-Related Injuries, Australia

2005-2006, Cat. No. 6324.0,

Canberra: ABS. URL:

http://www.ausstats.abs.gov.au/Ausst

ats/subscriber.nsf/

0/4C1F7A19EF4AEEA9CA2572490

018107D/\$File/63240_2005-06.pdf

Australian Institute of Health and Welfare .(2007). Australia's welfare 2007. Cat. No. AUS 93. Canberra: AIHW. URL:

https://www.aihw.gov.au/getmedia/e 41627b2-03f4-48fc-9432-

c119f45211aa/aw07.pdf.aspx?inline $=$ true

ASCC (Australian Safety and Compensation Council) (2008), Occupational Health And Safety Statistics Report 2003-2006, ASCC.

Anderson, D., Hannif, Z. and Lamm, F. (2011). The good, the bad and the ugly: The health and safety of young workers. In: Price, R., McDonald, P., Bayle, J. \& Pini, B. (eds.) Young People and Work. Ashgate Publishing Ltd.

Blair, Earl H., Seo, Dong-Chul, Torabi, Mohammad R. and Kaldahl, Mark A. (2004). Safety beliefs and safe behavior among midwestern college students. Journal of safety research, 35 , 131-140.

https://doi.org/10.1016/j.jsr.2003.11. 003 Get rights and content

Brosnan, Peter and Loudoun, Rebecca. (2006). Labour market experiences of teenage Australian workers in the 21 st century.Proceedings of the 20th Conference of theAssociation of Industrial Relations Academics of Australia and New Zealand (AIRAANZ). http://www.aomevents.com/conferen ces/AIRAANZ/index.php.

Chin, Peter. DeLuca, Christopher. Poth, Cheryl. Chadwick, Ingrid. Hutchinson, Nancy. And Munby, Hugh.(2010). Enabling youth to advocate for workplace safety. Safety science, 48, 570579.https://doi.org/10.1016/j.ssci.201 $\underline{0.01 .009}$

EASHW. 2007. "Young workers — Facts and figures: Youth employment." FACTS 69. Retrieved 14 October 2008, from http://osha.europa.eu/en/publications /factsheets/69.

Fraser, Christine. and David Fraser. (2002). Young people in Tasmania: a statistical and demographic profile of issuesand service provision for young people. Hobart, Tasmania, Office of Youth Affairs.

Hertzman, C., McGrail, K. and Hirtle, B.(1999). Overall Pattern of Health Care and Social Welfare Use by Injured Workers in the British Columbia Cohort. International Journal of Law and Psychiatry, 22(5-6), 581-601.

Hulshof CT, Verbeek JH, van Dijk FJ, et al. (1999). Evaluation research in occupational health services: general principles and a systematic review of empirical studies.Occupational and Environmental Medicine, 56, 361377.

Jahan, N., Pisaniello, D., Stewart, S., Braunack-Mayer, A. \& Winefield, H. (2010). Young worker injury experience in South Australia 19982007. Public Health, 7, 53-55.

Jovanović, Jovica. and Jovanović, Milan 2004. Occupational accidents and injuries: results of a safety preventive programme. Arh Hig Rada Toksikol. 55(4), 261-268. 
Knight, Elizabeth. B., Castillo, Dawn N., and Layne, Larry A. (1995). A detailed analysis of work-related injury among youth treated in emergency departments.American Journalof Industrial Medicine.27(6), 793-

805.https://doi.org/10.1002/ajim.470 $\underline{0270604}$

Laflamme, Lucie and Menckel, Ewa.(1995). Aging and occupational accidents a review of the literature of the last three decades. Safety Science 21(2), 145-161, https://doi.org/10.1016/09257535(95)00059-3

Palukka, P. and Salminen, Simo. (2005). Occupational accidents of the young and education. In International Symposium on Youth and Work Culture 2005. Finnish Institute of Occupational Health.

Pitman, Susan. 2003. Profile of young Australians.(2003). Facts, figures andissues. Foundation for Young Australians.

Rasmussen, K., Hansen, C. D., Nielsen, K. J. \& Andersen, J. H. (2011). Incidence of work injuries amongst Danish adolescents and their association with work environment factors. American journal of industrial medicine, 54, 143-152.

Runyan, Carol. W., Schulman, Michael, Del Santo, Janet. Bowling, Michael. Agans, Robert and Ta, Myduc. (2007). Work-Related Hazards and Workplace Safety of US Adolescents Employed in the Retail and Service Sectors.Pediatrics 119(3), 526-534.

Saarela, K. L. 2005. Promoting occupational safety of young workers-Different possibilities and approaches. In International Symposium on Youth and Work Culture 2005. Finnish Institute of Occupational Health.
Scott, D., Hockey, R., Barker, R., Sprinks, D. \& Pitt, R. 2004. Half the age twice the risk: Occupational injury in school age children. Injury Bulletin (Queensland Injury Surveillance Unit), 84.

Thamrin, Y., Pisaniello, D. \& Stewart, S. (2010). Time trends and predictive factors for safety perceptions among incoming South Australian university students. Journal of safety research, 41, 59-63. Available : http://www.sciencedirect.com/scienc e/article/pii/S0022437510000071

Tucker, S. \& Turner, N. (2011). Young worker safety behaviors: development and validation of measures. Accident, analysis and prevention, 43, 165-175.

Walters, J. K., A Christensen, K., K Green, M., E Karam, L. \& D Kincl, L. (2010). Occupational injuries to oregon workers 24 years and younger: An analysis of workers' compensation claims, 2000-2007. American journal of industrial medicine, 53, 984-994.

Webb, G., Redman, S., and Sanson-Fisher, R. (1992). Work injury experience at an industrial worksite. Journal of Occupational Health and Safety, Australia and New Zealand, 8(2), 143-153.

Westaby, J. D. \& Lowe, J. K. (2005). Risktaking orientation and injury among youth workers: examining the social influence of supervisors, coworkers, and parents. Journal of Applied Psychology, 90, 1027.

WorkSafe Victoria.(2007). Your health and safety guide to managing young workers. Subject Guide. No. 1 ed. Victoria, Australia: Work Safe Victoria.

Zierold, K. M. \& Anderson, H. A. (2006). Severe injury and the need for 
improved safety training among working teens. American journal of health behavior, 30, 525-532.

Zierold, K. M., Welsh, E. C. \& McGeeney, T. J. (2012). Attitudes of teenagers towards workplace safety training. Journal of community health, 37, 1289-1295. 